\title{
Linking phosphorus pools of water, sediment and macrophytes in running waters
}

\author{
G. Thiebaut, S. Muller \\ University of Metz, UFR Sci. F.A., UPRES EBSE, Equipe de Phytoécologie, Campus Bridoux, Avenue du Général Delestraint, \\ F-57070 Metz, France. E-mail: thiebaut@sciences.univ-metz.fr
}

\begin{abstract}
The aim of our paper was to study the space and time variations of phosphorus contents in the sediment, water and tissue of aquatic plants. Tissue Total Phosphorus of six aquatic plants (Callitriche platycarpa, C. hamulata, C. obtusangula, Elodea nuttallii, E. canadensis and Ranunculus peltatus) was analysed alongside the sediment Total Phosphorus (TP) and Soluble Reactive Phosphorus concentrations (SRP) in water, at the same site. Twelve sites were selected, and, samples were collected to test the seasonal and the annual patterns of phosphorus variation in 3 compartments. Streams ranged from oligotrophic to eutrophic waters. The sediments varied from mesotrophic to eutrophic states. A highly significant site effect was shown for water and for sediment. Water SRP varied with time (season, year), whereas no significant time effect was established for the sediment TP. Tissue TP varied according to year and season in Callitriche platycarpa, C. hamulata and E. nuttallii. The tissue phosphorus storage depended on the trophic level of sediment and water and varied according to species. The rank order of tissue TP content was $C$. obtusangula $>R$. peltatus $\geq E$. nuttallii $\geq$ E. canadensis $>C$. platycarpa $>C$. hamulata. Removal of aquatic plants biomass with its accumulated phosphorus could be an alternative technique to other eutrophication control strategies. Further work is needed to improve our knowledge to estimate the ecological risk of harvesting on biodiversity and on ecosystem function.
\end{abstract}

Keywords : Phosphorus fluctuation, aquatic plant, sediment, stream, management.

\section{Introduction}

Eutrophication produces changes in the level of phosphorus in all compartments of the phosphorus cycle, and has widespread and sometimes synergetic effects of increased plant growth, fluctuating dissolved oxygen levels, shallowing of the river-bed, summer flooding and loss of stenoxytherm species. For the planning of management programs, an understanding of the role of macrophyte in nutrient cycling is often required. Elucidation of the roles of plants in stream nutrient dynamics is far from being completed, while the phosphorus cycle is central to the understanding and management of eutrophication. The majority of freshwater eutrophication research during the past decades has focused on lakes and reservoirs, although the nutrient enrichment of flowing waters is also of great concern (Smith et al. 1999). The phosphorus dynamics of stream macrophytes have received only little attention to date (Madsen \& Adams 1988, Chambers et al. 1989, Robach et al. 1995, Pelton et al. 1998, Clarke \& Wharton 2001).
From a management perspective, the aquatic plants can significantly impact a system's light environment and nutrient budget (Reckhow \& Chapra 1999). Water plants have a great bearing on the phosphorus dynamics. Macrophyte species composition can alter sediment biogeochemistry resulting in varying porewater phosphate and solid-phase phosphorus and metal levels (Wigand et al. 1997). However, plants take up substances which they require for growth from the water, and secrete other substances. Phosphorus assimilation and storage in water plants depends on the vegetation type, and the plant growth characteristics (Reddy et al. 1999).

The sources of nutrients are obvious for plants of certain growth forms. Detached floating species such as Lemna must obtain nutrients from the water column, because there is no contact with the substrate. In principle, rooted macrophytes have access to two different nutrient sources, i.e. sediment and water column. For many years, controversy has existed regarding the role of roots versus shoots and sediment ver- 
sus open water in the nutrition of submersed aquatic macrophytes. The vast majority of work has been done in lentic alkaline waters, and a considerable amount of information has been accumulated. The conclusion of these extensive studies is that lacustrine sediments generally are a more important source of phosphorus than is lake water (Barko \& Smart 1980, Rattray et al. 1991). Most studies on lacustrine macrophytes have been conducted in chambers in laboratory (Denny 1972, DeMarte \& Hartman 1974, Bole \& Allan 1978, Best \& Mantai 1979, Barko \& Smart 1980, Gabrielson et al. 1984, Smart \& Barko 1985, Best et al. 1996). These stagnant conditions are not appropriate for macrophytes, whose ecology is dependent on water flow. Experiments, which have tried to exhibit the relative importance of sediments or water as sources of nutrients are inconclusive, and further work is needed to establish how sediment nutrient characteristics vary within and among rivers (spatially and temporally) and the relationships between sediment nutrients, water column chemistry and macrophytes (Clarke \& Wharton 2001).

Several attempts have been made to relate the extent of nutrient uptake to concentrations in the environment by measuring concentrations of nutrients in plant tissues (Royle \& King 1991, Robach et al. 1995). Tissue phosphorus concentration have been found to be different in different parts of submersed angiosperms (Rorslett et al. 1985, Duarte 1992) and in plants collected at different times of the year (Gerloff \& Krombohlz 1966, Rorslett et al. 1985, Madsen \& Adams 1988, Royle \& King 1991, Robach et al. 1996).

To understand the relationship between macrophytes and nutrients in streams, research is needed to establish the spatial and temporal variability of macrophyte nutrient concentrations in streams, and the link to water column chemistry; and specify the relationships between sediment, water and macrophyte species. The aim of this paper is to present the results of a study regarding the space and time pattern of sediment TP, of water SRP, and of tissue TP content in six aquatic macrophytes.

\section{Study area, material and methods}

The study area is situated in north-eastern France, in the Biosphere Reserve of the Northern Vosges, close to the German border. The landscape pattern of the Northern Vosges consists of sandstone mountains of 200$580 \mathrm{~m}$ in altitude topped by rocky conglomerate surrounded by steep cliffs. Winters are cold with more than 100 days of frost; summers are relatively hot. The mean annual temperature is $8.6{ }^{\circ} \mathrm{C}$. The mean annual rainfall is $900 \mathrm{~mm}$. The regional climate is sub-continental. The studied streams are located in the Moder catchment (Fig. 1). They drain a forested area covered by acidic soils ranging from brown acidic soils to podzolic soils. The hydrological network flows in alluvial deposits poor in calcium carbonate. The sandstone streams are shallow. Twelve sites were selected in order to represent a wide range of trophic conditions, and to determine the variations in streams with differences or changes in physicals characteristics (depth, width, substrata, habitats, flow velocity, shading, bed stability, water clarity) along their length. The physical characteristics of each site were also recorded.

The sampling was conducted in the spring, summer and autumn of 1995, 1998 and 1999. During each period, 12 water samples, 12 mixed sediment samples and 46 aquatic plant mixed samples (12 samples of Callitriche platycarpa, 9 samples of $C$. hamulata, 7 samples of $C$. obtusangula, 7 samples of Ranunculus peltatus, 7 samples of Elodea nuttallii and 4 samples of $E$. canadensis) were collected.

At each site, a water sample was collected from the centroid of flow in a $500 \mathrm{ml}$ polyethylene bottle, which had been pre-rinsed with streamwater. Streamwater samples were analysed in the laboratory. SRP in water was analysed by the standard molybdenum blue analytical technique (AFNOR, 1990). Sediment cores were taken, and subsequently sampled in the first $5 \mathrm{~cm}$, corresponding to the root layer. Sediment samples were oven dried $\left(65^{\circ} \mathrm{C}\right)$ during 3 days and ground, prior to analysis for total phosphorus TP.

The distribution of the aquatic plants was unequal in the area. Two species were widely distributed, Callitriche platycarpa (frequency: $100 \%$ ), Callitriche hamulata (frequency: $75 \%$ ), while Ranunculus peltatus, Callitriche obtusangula and Elodea nuttallii (frequency: $58 \%$ ) were less frequent in the studied network. The last species Elodea canadensis was rare (frequency: $33 \%)$. At each sampling site, the selected plant species (Callitriche hamulata, C. platycarpa, C. obtusangula, Ranunculus peltatus, Elodea nuttallii and $E$. canadensis) were taken from stands with at least three samples per species (each from different stands). Samples were located randomly within macrophyte stands. They were rinsed with care in the laboratory, oven dried $\left(65^{\circ} \mathrm{C}\right)$ during 3 days, and ground, prior to tissue analysis for TP. TP was determined in the plants and sediment samples after digestion using perchloride acid, and nitric acid, and analysed using the molybdenum blue analytical technique (AFNOR, 1990). 


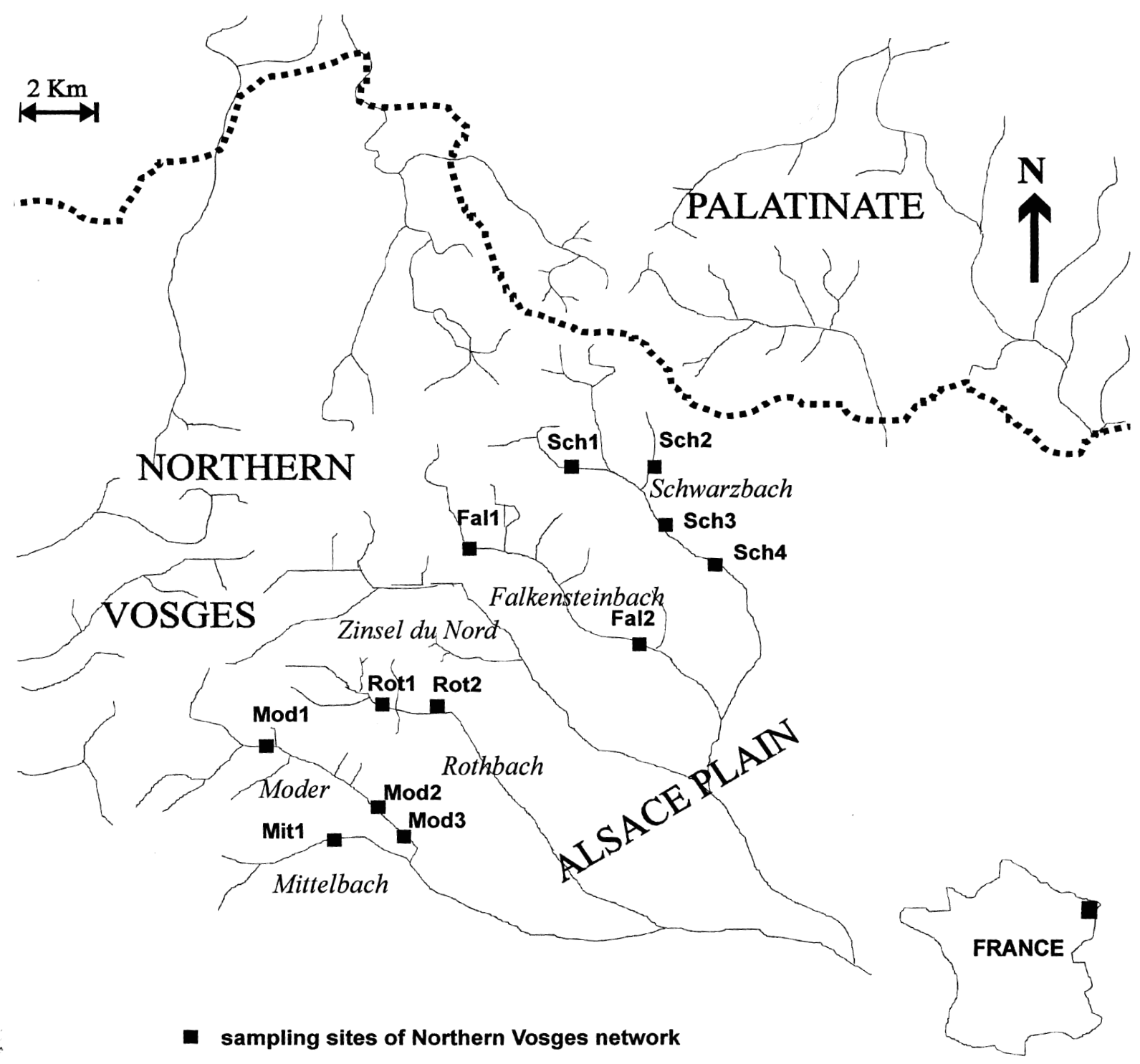

Fig.1. Location of the 12 sampling sites.

The spatial and the temporal variability of the sediment, water, and macrophyte phosphorus contents were analysed. A comparison of mean values for TP and for SRP variables was undertaken by analysis of variance (ANOVA) test. ANOVA assumptions were fullfilled (normal population; equal variances). Time and space effects were statistically considered to be significant at $p$ values $p<0.05$. A linear regression was performed, and a Pearson's correlation coefficient calculated between «SRP» in water and TP in sediment.

\section{Results}

\section{Soluble Reactive Phosphorus in water}

A significant time (seasonal and annual) effect was established for SRP in open-water by analysis of variance (Table 1). The mean SRP value of the year 1999 was significantly lower than the mean SRP values of the years 1995 and 1998. The highest SRP was observed in autumn, and the lowest one in spring. No significant interaction was established between year and 
Table 1. Summary of the results of ANOVAs, providing information on space and time variability of Total Phosphorus of sediment and of Soluble Reactive Phosphorus of water in an indirect way. ns: non significant, df: degree of freedom, $\mathrm{p}$ : significance.

\begin{tabular}{lcccccc}
\hline & \multicolumn{3}{c}{ SRP water } & \multicolumn{3}{c}{ TP sediment } \\
& $\mathrm{F}$ & $\mathrm{p}$ & $\mathrm{df}$ & $\mathrm{F}$ & $\mathrm{p}$ & $\mathrm{df}$ \\
\hline year & 6.48 & 0.040 & 2 & 0.75 & $\mathrm{~ns}$ & 2 \\
season & 7.37 & 0.002 & 2 & 0.69 & $\mathrm{~ns}$ & 2 \\
sites & 20.35 & 0.000 & 11 & 7.01 & 0.000 & 11 \\
\hline
\end{tabular}

season. Figure 2 illustrates the variability of water SRP among and within sites. The spatial variability of SRP was investigated by performing an ANOVA test. The results of these tests indicate that for SRP, the means were significantly different among the 12 site $(\mathrm{p}<0.001)$. Mean SRP value ranged from oligotrophic (site Sch1: $\left[\mathrm{P}_{-} \mathrm{PO}_{4}{ }^{3-}\right]$ : $14 \pm 1 \mu \mathrm{g} / \mathrm{l}$ ) to eutrophic water (site Mit1: $\left[\mathrm{P}_{-} \mathrm{PO}_{4}{ }^{3-}\right]$ : $196 \pm 20 \mu \mathrm{g} / \mathrm{l}$ ). The latter value greatly exceededs the eutrophic SRP boundary of $100 \mu \mathrm{g} / \mathrm{l}$.

\section{Total Phosphorus in sediment}

No significant time effect (seasonal and annual) was established for TP in sediment (Table 1). Sediment TP content showed highly significant differences between the sites (ANOVA, $\mathrm{p}<0.001$, Table 1). Mean TP value ranged from oligotrophic (site Sch $1:[\mathrm{TP}]: 0.72 \pm 0.20$ $\mathrm{mg} / \mathrm{gDW}$ ) to eutrophic sediment (site Mod3: [TP] : $2.23 \pm 0.40 \mathrm{mg} / \mathrm{gDW}$ ), as it is shown in Fig. 3 .

Concentration of Total Phosphorus in macrophyte shoots

Site-to-site differences in tissue phosphorus concentrations, as indicated by the magnitude of the standard error relative to the mean, were substantial. Tissue TP contents changed from upstream to downstream (Fig. 4), and according to river. Tissue TP content increased from upstream (site Fal 1) to downstream for

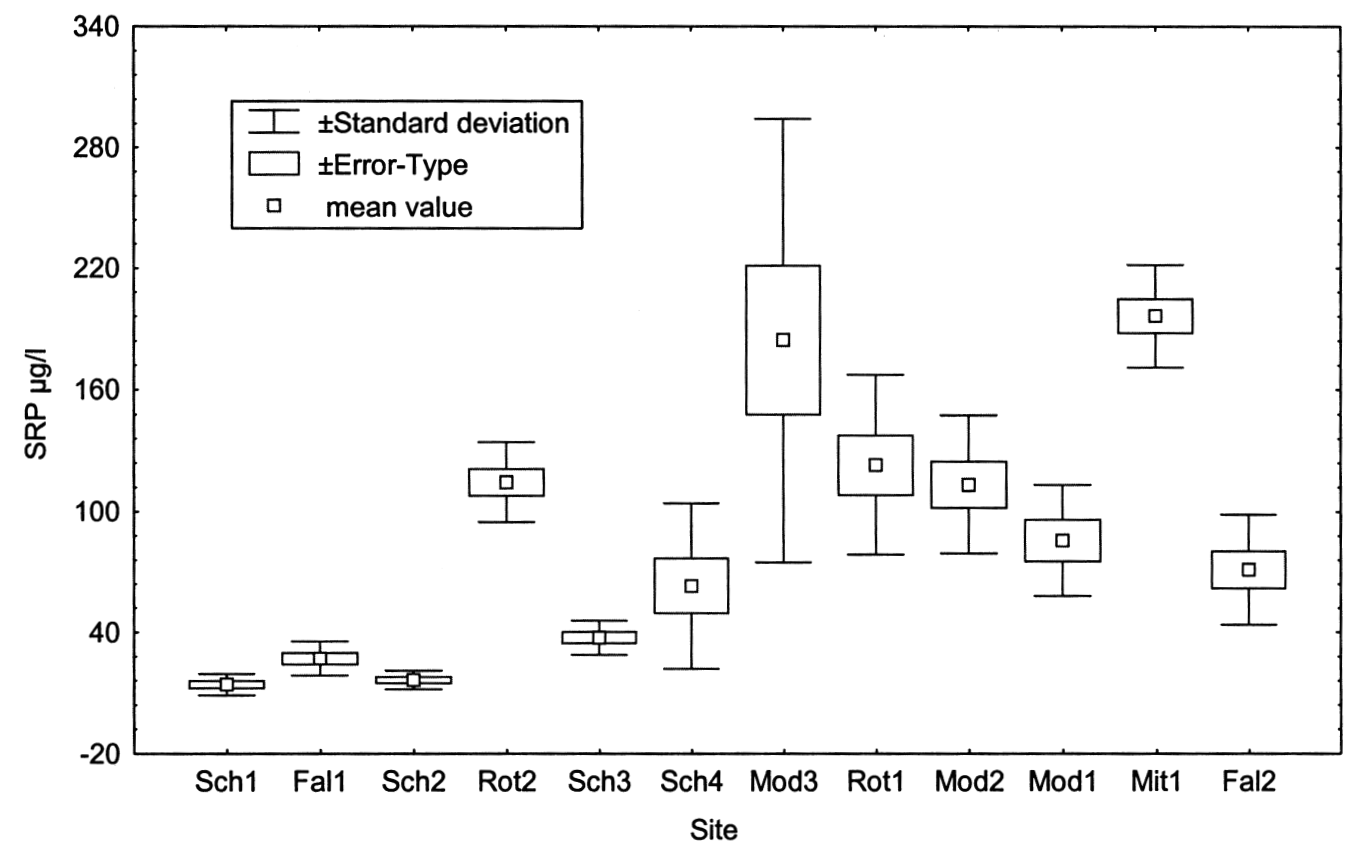

Fig. 2. Boxplots of water SRP versus sites (mean value). Values were obtained from 9 samples from each site. 


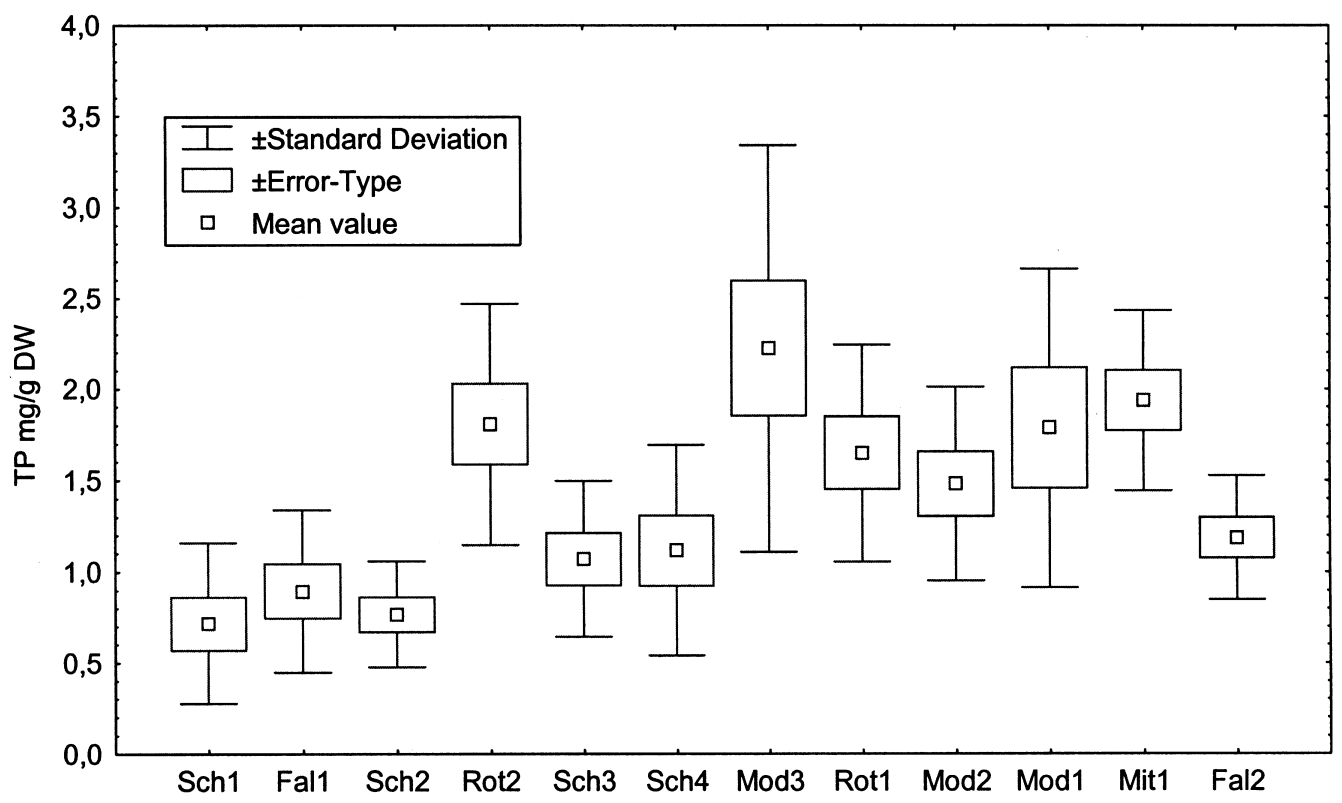

Fig. 3. Boxplots of Total Phosphorus (TP) of sediment versus sites (mean value). Values were obtained from 9 samples from each site.

Elodea nuttallii (site Fal 2; ANOVA, p < 0.001) in the Falkensteinbach, whereas no significant difference was measured in the Moder river (site Mod1, 2, 3). An annual effect was demonstrated to be significant for all species (ANOVA test, Table 2). However, no significant seasonal variation of TP was established for $R$. peltatus, $C$. obtusangula and for E. canadensis (Table $2)$. The lowest TP concentration was measured in spring, and the highest value was obtained in autumn in E. nuttallii, $C$. platycarpa, and $C$. hamulata tissues (ANOVA, $\mathrm{p}<0.05$ ). A highly significant species effect could be demonstrated (ANOVA, $\mathrm{p}<0.001$, Fig. 5). Tissue TP content differed according to species. The 3 Callitriche taxa revealed an aptitude for $\mathrm{P}$ storage (ANOVA, $\mathrm{p}<0.001$ ), different from the other species.

Relationships between sediment, water and aquatic plants nutrient contents

Figure 6 illustrates a highly significant linear regression between water SRP and sediment TP $\left(\mathrm{r}^{2}=0.92\right.$, $\mathrm{p}<0.001)$. Significant positive correlations were found between sediment TP and tissues TP for $R$. pel-

Table 2. Summary of the results of ANOVAs, providing information on space and time variability of Total Phosphorus content in 6 aquatic plants in an indirect way. ns: non significant, df: degree of freedom, p: significance.

\begin{tabular}{lcccccc}
\hline & \multicolumn{3}{c}{ Annual effect } & \multicolumn{3}{c}{ Seasonal effect } \\
& $\mathrm{F}$ & $\mathrm{df}$ & $\mathrm{p}$ & $\mathrm{F}$ & $\mathrm{df}$ & $\mathrm{p}$ \\
\hline C. hamulata & 5.11 & 2 & 0.009 & 7.27 & 2 & 0.001 \\
C.obtusangula & 18.77 & 2 & 0.001 & 2.45 & 2 & $\mathrm{~ns}$ \\
C. platycarpa & 4.98 & 2 & 0.009 & 7.62 & 2 & 0.001 \\
E.canadensis & 4.90 & 2 & 0.020 & 0.92 & 2 & $\mathrm{~ns}$ \\
E.nuttallii & 4.15 & 2 & 0.020 & 7.63 & 2 & 0.020 \\
R.peltatus & 8.60 & 2 & 0.001 & 1.58 & 2 & $\mathrm{~ns}$ \\
\hline
\end{tabular}



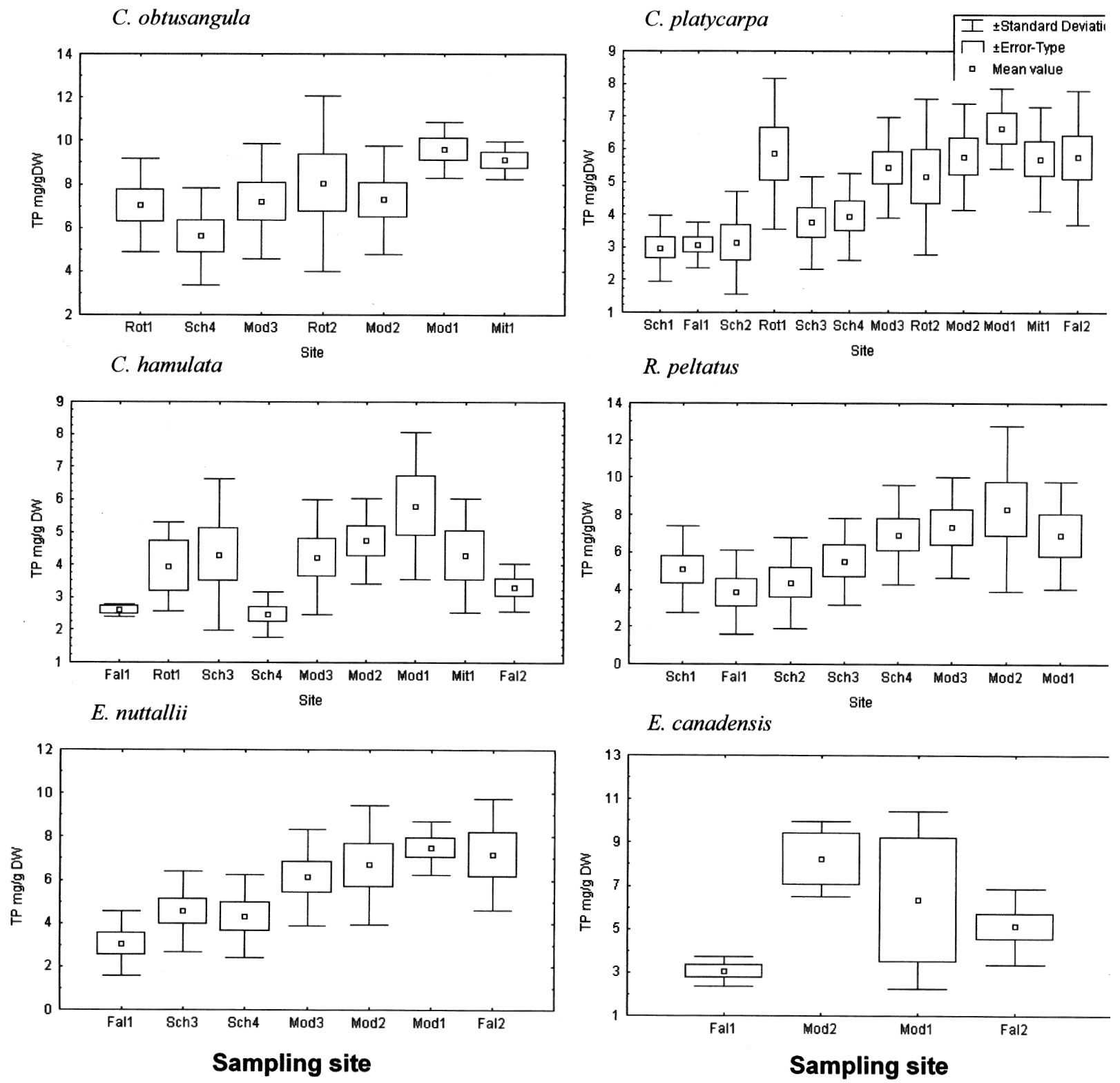

Fig. 4. Boxplots of Total Phosphorus of 6 aquatic plants versus sites (mean value). Values were obtained for 9 samples from each site. 


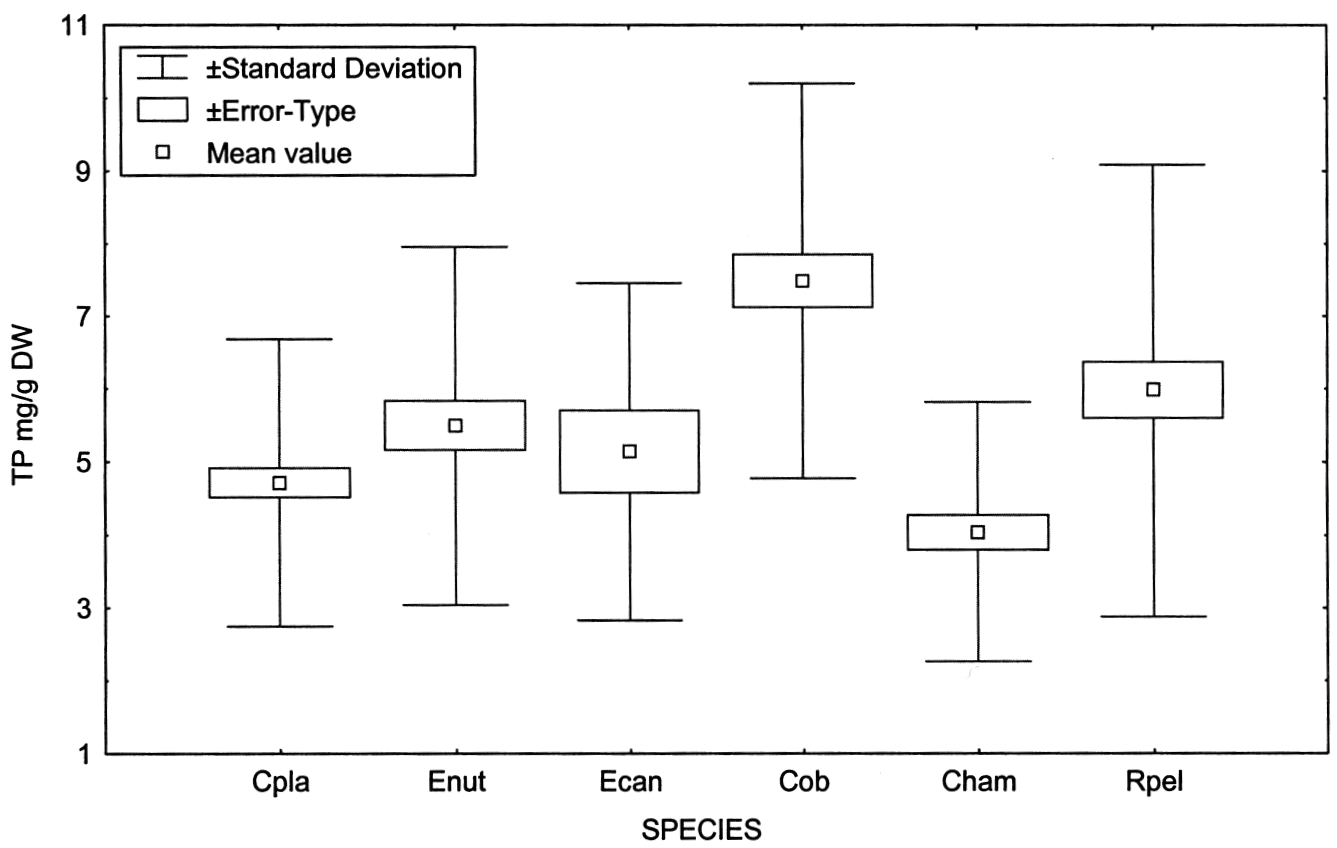

Fig. 5. Boxplots of tissue Total Phosphorus versus species (mean value).

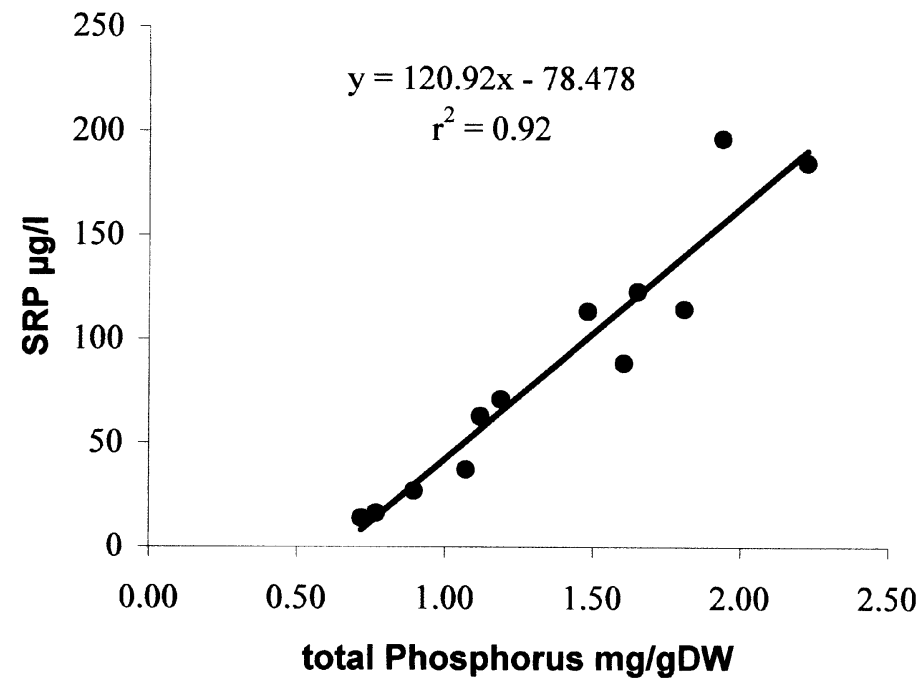

Fig. 6. Correlation between SRP of water and TP of sediment. 
Table 3. Relationships between SRP of water and TP of plants, and between TP of sediment and TP of macrophytes (mean values). $\mathrm{r}^{2}$ : Pearson correlation coefficient, ns: non significant $*: \mathrm{p}<0.1, * *: \mathrm{p}<0.05, * * *: \mathrm{p}<$ 0.001 .

\begin{tabular}{lcc}
\hline & SRP water & P sediment \\
\hline & & \\
C. hamulata & $\mathrm{ns}$ & $\mathrm{ns}$ \\
C. platycarpa & $\mathrm{r}^{2}=0.72^{\star \star}$ & $\mathrm{r}^{2}=0.84^{\star \star \star}$ \\
C.obtusangula & $\mathrm{ns}$ & $\mathrm{r}^{2}=0.66^{\star}$ \\
E.nuttallii & $r^{2}=0.69^{\star}$ & $r^{2}=0.75^{\star}$ \\
E.canadensis & $r^{2}=0.95^{\star}$ & $\mathrm{ns}$ \\
R.peltatus & $r^{2}=0.77^{\star}$ & $r^{2}=0.79^{\star}$ \\
\hline
\end{tabular}

tatus, E. nuttallii, C. obtusangula and C. platycarpa (Table 3). Significant positive correlations were also found between SRP in the water column and TP in plant tissues for $E$. nuttallii, E. canadensis, $R$. peltatus and $C$. platycarpa (Table 3). No significant correlation was measured between TP in $C$. hamulata tissues and TP of sediment or between TP in this plant, and SRP in water.

\section{Discussion}

\section{Fluctuating phosphorus bioavailability}

A significant variation of SRP in open water and TP in sediment was established according to site. The reduction of phosphorus loading from uplands depends on the assimilation capacity of streams. It involves physical, biological and chemical processes that retain phosphorus. The influence of flow variability within the channel will enhance the spatial variation in sediment chemistry with turbulence (Boström et al. 1988). The pattern of phosphorus inputs to a river can greatly vary depending upon the natural conditions and human activities (domestic effluents, fertilization). The absence of TP time variability in sediment could be explained by water flow velocity which displaced sediment, and induced a heterogeneity of sediment. The values obtained for TP in stream sediments are comparable with TP values quoted in the literature, for example 154 - $2247 \mu \mathrm{g} / \mathrm{g}$ (Clarke \& Wharton 2001).

Space and Time phosphorus content fluctuation in aquatic macrophytes

Phosphorus concentrations remained above critical concentrations $(1.3 \mathrm{mg} / \mathrm{g}$ dry plant weight, value suggested by Gerloff \& Krombholz 1966), during the gro- wing season, indicating by that this nutrient did not limit macrophyte growth in the most oligotrophic site. The phosphorus storage in plants depended on the trophic level of water and sediment. In the study area, the TP in tissue was highest in aquatic plants growing in eutrophic water, than in those in oligotrophic water. High tissue phosphorus loads were measured in sites receiving nutrient-rich effluents (Rot1, 2, Mod1, 2, 3, Mit1). The significant correlation between SRP and aquatic plant, and between TP in sediment and TP in macrophyte indicated that the space variability of TP in tissue could be explained by the substrate and by the water trophy level. The low tissue phosphorus concentrations at sites with sandy sediment (Sch1, Sch2), or with low trophic level of water, reflect low phosphorus availability in such sediments and in streamwater, or poor root penetration of aquatic macrophytes ( $E$. nuttallii, $R$. peltatus, $C$. platycarpa) into a coarse substrates. Possible links between TP in sediments and macrophyte biomass could be desorption of SRP, decomposition of particulate organic matter, or leaching by roots exudates of macrophytes. Macrophytes can be important transient storage structure by acting as deadzones with high nutrient turnover, and by providing quiescent conditions for the settling of seston. However, given the wide range of influences upon macrophytes in rivers it is possible that, for many species, sediment characteristics are of minor importance providing macrophytes are able to anchor firmly and there are no phytotoxic effects (Clarke 2002). This preliminary analysis of the correlations between SRP and macrophyte, and between TP in sediment and TP in aquatic plant shows that the relationships between aquatic macrophytes and the trophic status of rivers is complex one, partly because of the effects of a wide range of environmental variables and partly because rooted macrophytes can absorb nutrients from the riverbed sediment and the water column (Clarke \& Wharton 2001). More research is needed to ascertain the effect of flow, sediment characteristics and plant ecophysiology upon macrophyte and trophic status of small mountainous streams.

The P storage ability also differed according to species. The rank order of tissue TP content was C. obtusangula $>R$. peltatus $\geq E$. nuttallii $\geq E$. canadensis $>$ $C$. platycarpa $>C$. hamulata. Comparison between the taxa must be made with caution, because of their morphological and anatomical differences. However, the three Callitriche species revealed a trend of great aptitude for P storage in C. obtusangula to little for C. hamulata, whereas the two Elodea species had a similar ability of TP storage. C. obtusangula was restricted to 
eutrophic streams in Northern Vosges, whereas $C$. hamulata occurred from oligotrophic to eutrophic sites. The two Elodea species had the same trophic pattern in our area. $R$. peltatus and $C$. platycarpa colonised from oligotrophic to eutrophic water and sediment.

The phosphorus contents were high at the end of summer or at the beginning of autumn, and the biomass was great for E. nuttallii (Best and Dassen 1987) and low for $R$. peltatus, at the end of summer or in autumn. Macrophyte biomass of $E$. nuttallii was low in spring, and little material could be obtained by harvesting, whereas $R$. peltatus biomass was the highest at that time. Possible explanations for seasonal changes of phosphorus in macrophyte tissues are the changes in epiphyte load or adsorbed phosphorus, both of which would confound internal tissue TP measurements. However, Jones et al. (2000) established that increased phosphorus loading had no effect on the abundance of periphyton growth. Periphyton and vascular plants were competing for carbon, and not for nutrients. Seasonal changes could be controlled by the annual growth and decomposition of aquatic vascular plants.

\section{Implications for management ?}

The efficiency of harvesting as a eutrophication control strategy depends on the plant (species, biomass, phenology, morphology, reproductive strategy), on the water column (SRP concentration, flowing/still waters, mineralisation), and on the sediment (type, TP, organic matter). Phosphorus retention in streams is not well known, and it would be useful to improve our knowledge to estimate the potential effects of harvesting on nutrient cycling in streams. Macrophytes store nutrients during the vegetation period and release after senescence in autumn, when phytoplancton blooms are not likely to occur anymore. To avoid the release of nutrients in autumn, plants should be carefully collected from the streams. Cutting with removal of plant material may introduce additional problems with the floating and decaying plant material and the risk of colonisation downstream.

Some studies evaluated $\mathrm{P}$ removal under high nutrient loads and periodic harvesting. They established that $\mathrm{P}$ mass removal by aquatic plants is correlated with the P mass loading (Carpenter and Adams 1977, Dierberg et al. 2002). These studies corroborate our finding that macrophytes could be an important reservoir for nutrients and could reduce loads in the summer, whereas, some others studies in eutrophic streams (i.e., Madsen and Adams 1988) indicated that macrophytes would not reduce phosphorus loads to downstream reaches. Van Nes et al. (2002) analyzed the res- ponse of an aquatic plant population, subjected to harvesting by means of a simple generic model and a more complex and realistic model. Though their results indicate that it should be possible to use selective harvesting successfully, it is still difficult to predict the outcome of such strategy. It is not clear how harvesting affect the plant biomass. The plants may regrow rapidly, even to a higher density than before harvesting, or may cause complete loss of vegetation. Even moderate harvesting may reduce the resilience of the vegetated state, making the ecosystem more vulnerable to adverse conditions (van Nes et al. 2002). Apart from the reduced availability of macrophytes for consumption by water birds and the reduced area of sediment covered by plants, cutting the plants may have several other adverse effects as well, ranging from high management costs, mortality among fish and macro-invertebrates, resuspension of soft sediments, and the stimulation of cyanobacterial blooms...

Removal of aquatic plants biomass with its accumulated phosphorus is an alternative technique amending other eutrophication control strategies (reduction of nutrient loads, managing the existing high-nutrient state to minimise the adverse biological and chemical effects). The recommendation of harvesting macrophytes to reduce nutrient loads is only valid for oligotrophic small streams in mountainous areas. If such management is proposed an adequate evaluation of the real effect and ecological risk should be analyzed.

\footnotetext{
Acknowledgements

Many thanks to Jacques Belliard with his assistance for statistical data analyses.

\section{References}

AFNOR 1990. - Recueil des normes françaises. Eaux. Méthodes d'essais. 4ème ed, Paris, 736 p.

Barko J.W. \& Smart R.M. 1980. - Mobilization of sediment phosphorus by submerged freshwater macrophytes. Freshwat. Biol., 10, 229-238.

Best E.P. \& Dassen J.H.A. 1987. — A seasonal study of growth characteristics, and the levels of carbohydrates and proteins in Elodea nuttallii, Polygonum amphibium and Phragmites australis. Aquat. Bot., 28, 353-372.

Best E.P.H., Woltman H. \& Jacobs F.H.H. 1996. — Sediment-related growth limitation of Elodea nuttallii as indicated by a fertilization experiment. Freshwat. Biol., 36, 33-44.

Best M.D. \& Mantai K.E. 1979. — Growth of Myriophyllum: sediment or lake water as the source of nitrogen and phosphorus. Ecology, 59, 1075-1080.

Bole J.B. \& Allan J.R. 1978. - Uptake of phosphorus from sediment by aquatic plants, Myriophyllum spicatum and Hydrilla verticillata. Water Res., 12, 353-358.

Boström B., Andersen J.M., Fleisher S. \& Jansson M. 1988. — Exchange of phosphorus accros the sediment-water surface. Hydrobiologia, 170, 229-244.
} 
Carpenter S.R. \& Adams S.A. 1977. — The macrophyte tissue nutrient pool of hardwater eutrophic lake: implications for macrophyte harvesting. Aquat Bot., 3, 239-255.

Chambers P.A., Prepas E.E., Bothwell M.L. \& Hamilton H.R. 1989. - Roots versus shoots in nutrient uptake by aquatic macrophytes in flowing waters. Can. J. Fish. Aquat. Sci., 46, 435-439.

Clarke S.J. 2002. - The sediment niche of riverine macrophyte species. Proceedings of the $11^{\text {th }}$ EWRS International Symposium on Aquatic Weeds, Moliets et Maâ (France), 2-6 September 2002, 107-110.

Clarke S.J. \& Wharton G. 2001. — Sediment nutrient characteristics and aquatic macrophytes in lowland English rivers. Sci. Tot. Env., 266, 103-112

DeMarte J.A. \& Hartman R.T. 1974. - Studies on absorption of ${ }^{32} \mathrm{P}$, ${ }^{59} \mathrm{Fe}$ and ${ }^{45} \mathrm{Ca}$ by water-milfoild (Myriophyllum excalbescens $\mathrm{Fer}-$ nald). Ecology, 55, 188-194.

Denny P. 1972. - Sites of nutrient absorption in aquatic macrophytes. J. Ecol., 60, 819-929.

Duarte C. 1992. - Nutrient concentration of aquatic plants: Patterns accross species. Limnol. Oceanogr., 37, 882-889.

Gabrielson J.O., Perkins M.A. \& Welch E.B. 1984. — The uptake, translocation and release of phosphorus by Elodea densa. Hydrobiologia, 3, 43-48.

Gerloff G.C. \& Krombholz P.H. 1966. — Tissue analysis as a measure of nutrient availability for the growth of angiosperm aquatic plants. Limnol. Oceanogr., 11, 529-537.

Jones J.I., Eaton J.W. \& Hardwick K. 2000. — The effect of changing environmental variables in the surrounding water on the physiology of Elodea nuttallii. Aquat. Bot., 66, 115-129.

Madsen J.D. \& Adams M.S. 1988. - The nutrient dynamics of a submersed macrophyte community in a stream ecosystem dominated by Potamogeton pectinatus. J. Freshwat. Ecol., 4, 541-550.

Pelton D.K., Levine S.N. \& Braner M. 1998. - Measurements of phosphorus uptake by macrophytes and epiphytes from the La Platte River (VT) using ${ }^{32} \mathrm{P}$ in streams microcosms. Freshwat. Biol., 39, 285-299.
Rattray M.R., Howard-Williams C. \& Brown J. M. 1991. — Sediment and water as sources of nitrogen and phosphorus for submerged rooted aquatic macrophytes. Aquat. Bot., 40, 225-237.

Reckhow K.H. \& Chapra S.C. 1999. - Modelling excessive nutrient loading in the environment. Environ. Poll., 100, 197-207.

Reddy K.R., Kadlec R.H., Flaig E. \& Gale P.M. 1999. - Phosphorus retention in streams and wetlands: a review. Critical Rev. Environ. Sci. Tech., 29, 83-146.

Robach F., Hajnsek I., Eglin I. \& Trémoliéres M. 1995. — Phosphorus sources for aquatic macrophytes in running waters: water or sediment ? Acta bot. Gallica, 142, 719-731.

Robach F., Merlin S., Rolland T. \& Trémolières M. 1996. — Assimilation et stockage du phosphore par des macrophytes aquatiques bioindicateurs du niveau trophique de l'eau. Ecologie, 27, 203-214.

Rorslett B., Berge D. \& Johansen S.W. 1985. - Mass invasion of Elodea canadensis in a mesotrophic, South Norwegian lake- impact on water quality. Verh. Internat. Verein. Limnol., 22, 2920 2926.

Royle R.N. \& King R.J. 1991. — Aquatic macrophytes in Lake Liddle, New south Wales: biomass, nitrogen and phosphorus status, and changing distribution from 1981 to 1987. Aquat. Bot., 41, 281-298.

Smart R.M. \& Barko J.W. 1985. — Laboratory culture of submersed freshwater macrophytes on natural sediments. Aquat. Bot., 21, 251-263.

Smith V.H., Tilman G.D. \& Nekola J.C. 1999. — Eutrophication: impact of excess nutrient inputs on freshwater, marine, and terrestrial ecosystems. Environ. Poll., 100, 179-196.

van Nes E.H, Scheffer M., van der Berg M.S. \& Coops H., 2002. Aquatic macrophytes: restore, eradicate or is there a compromise? Aquat Bot., 72, 387-403.

Wigand C., Stevenson J.C. \& Cornwell J.C. 1997. — Effects of different submersed macrophytes on sediment biogeochemistry. Aquat. Bot., 56, 233-244. 